\title{
Modern Intensive Dairy Beef Production Systems in Russia
}

\author{
G. P Legoshin ${ }^{1}$, E. S., Afanasyeva ${ }^{1}$, O. N., Mogilenetz ${ }^{1}$, T. G. Sharafeeva ${ }^{1} \&$ A. P. Mamonov ${ }^{1}$ \\ ${ }^{1}$ All-Russian Research Institute for Animal Husbandry Named after Academy Member L.K. Ernst, L.K. Ernst \\ Institute of Animal Husbandry, 142132 Dubrovitsy, Podolsk district, Moscow Region, Russia
}

Correspondence: G. P. Legoshin, L.K. Ernst Institute of Animal Husbandry, 142132 Dubrovitsy, Podolsk district, Moscow Region, Russia. E-mail: vijLegoshin@yandex.ru

Received: August 15, 2014

Accepted: September 4, 2014

Online Published: October 23, 2014

doi:10.5539/mas.v8n6p170

URL: http://dx.doi.org/10.5539/mas.v8n6p170

\begin{abstract}
The objective of this study was to determine the biological and economic efficiency of growing-finishing young dairy bulls slaughtered at different live weights under current consumer's requirements and market conditions. Experiment was conducted with bull calves of Black and White breed with high level (>85\%) Holstein blood $(\mathrm{n}=60)$. All animals were indoor housed and fed on diets consisting of forage (55 percent on dry matter basis) and concentrate (45 percent) with flat daily live weight gains $900-1000 \mathrm{~g}$. The overall findings for the dairy calf to beef system can be summarized as follows. Under current conditions optimum slaughter weights of young bulls are $500-550 \mathrm{~kg}$ at the ages of 17-18 months. Biological efficiency as measured by carcass weight production per animal, carcass and meat qualities, increased with increasing of slaughter weights from 400 to $550 \mathrm{~kg}$. The same pattern has occurred for net return, but profitability was unchanged. Production systems with light slaughter live weights require more number of cattle by 14-41 percent to produce the same carcass weights. On the other hand feed conversion of the bulls slaughtered at light live weights was higher. Meat potential of Black and white breed with high proportion of Holstein blood is good enough to produce quality lean carcasses.
\end{abstract}

Keywords: dairy beef, biological and economic efficiency, carcass characteristics, meat quality

\section{Introduction}

In Russia, about 87 percent of beef meat production stems from the fattening of young dairy bulls and cull dairy cows (Legoshin and Sharafeeva, 2013). In the last 20 years the number of dairy cattle was decreased from above 50 million head to 20 million head and has tendency to continue this decreasing. It means (a) decreasing of possibilities of dairy beef production, (b) the objective necessarity of developing of large-scale beef cattle husbandry and the intensification of use decreased fattening contingent to produce more beef meat. Thus dairy beef production plays now and will play in the future very important role in Russia.

The main parameters of dairy beef production systems were described in several reports. For example, Hardy and Meadowcroft, 1990, have shown efficient systems of indoor beef production in Grait Britain, Dunne and O'Neil, 1996, Fallon at al., 2001, Keane, 2003, Walsh at al., 2008, have reported many aspects of dairy beef production systems based on grass and grass silages in Ireland.

Many studies were conducted to indicate the optimal duration of fattening, ages and live weights of animals at finish. For example, Boreš and Bartoň, 2012 (Czech Republic), have shown that Charolais x Simmental bulls and heifers slaughtered at age of 18 months and live weights 698 and $553.7 \mathrm{~kg}$, respectively, in comparison with analogs slaughtered at age of 14 months and live weights of 554 and $478.7 \mathrm{~kg}$ obtained higher scores for beef flavor, intensity, tenderness, juiciness and overall acceptance of meat. But it was clearly indicated by many studies, that there are a lot of variations in slaughter ages and live weights of animals from country to country. These parameters are dependent on breeds, sex, genetic potential, quality and quantity of feeds, market conditions and some other factors (Alberti et al., 2008, Alberti et al., 2005, Anderson et al., 2005, Antal et al., 1988, Brosh et al., 1995, Cuvelier et al., 2006, French et al., 1998, Frickh et al., 2002, Keane and Fallon, 2001, Keane and Darby, 2000, Kwon et al., 2009, Legoshin et al., 1995, Mossberg et al., 1992, O'Neil and Dunne, 1995, Orkisz, 1988, Rodbotten et al., 2002, Steinwidder et al., 2002, Waritthitham et al., 2010). On the other hand all beef production systems have to be examited from time to time to find out the advantages and disadvantages of different ages and live weights of animals at slaughter under modern conditions. Until relatively recently, intensive dairy bull calves growing-finishing system, so-called Voronovo's technology, was 
the most popular among the beef producers in Russia. The main features of this system include the start rearing at $45-50 \mathrm{~kg}$ of live weights, finish at ages 13-14 months and $400 \mathrm{~kg}$ of live weights, flat daily live weight gain 900-1000 g, rations based on concentrates (60-65 percent on dry matter basis) and forage (grass or corn silages and small quantity of hay), indoor housing. This system was economically efficient under specific conditions and among them low demand and low prices on calves and good prices for fattened animals. At the modern time there are deficit of calves and feeders, high level of competition of beef with pork and chicken, high prices on grains. Meat industry requirement is to get the fattened cattle with higher live weights. In this connection the first goal of our study was to determine the optimum live weights at which dairy bull calves attain an acceptable degree of finish associated with a carcass characteristics and meat quality of high classes in accordance with Russian and international standards and to examine economic efficiency of dairy beef production systems.

There are some information that the increased proportion of Holstein blood in the dairy herd may have negative consequences for dairy beef production. Mc Gee et al., 2007, have found that high dairy genetic merit Holstein bulls in comparison with standard dairy genetic merit Friesian bulls had significantly higher values for withers height, pelvic height and chest depth, but narrower chest and a longer back, their carcasses had almost the same weights but much less fleshiness scores. Over 72 percent of dairy cattle population in Russia belong to Black and White $(57.38 \%)$, Holstein $(5.44 \%)$, Simmental $(9.20 \%)$ and very closed to Simmental Sychevskaya $(0.53 \%)$ breeds. Proportion of Holstein blood in Black and White population increases with every year through use of Holstein sires and now consists of more than $50 \%$ and even up to $90 \%$ at the farms in regions with intensive milk production (Amerchanov et al., 2013). Taking into consideration these figures our second aim was to estimate the current meat potential of the young bulls of main breed type.

The feeds are the main variable costs in beef production and can account for over $70 \%$ of all costs. In the most countries in the world, including Russia the hays, haylages and silages significantly cheaper (by $25-35 \%$ and more) than cereals and other concentrates. Proportion of concentrates in the diets for growing-finishing bulls depends on prices of different feeds and quality of forage and can vary from 30 to $65 \%$ for all cycle of growing finishing period and up to over $80 \%$ for finishing stage at feedlots (Boreš and Bartoň, 2012, Clinquart et al., 1991, Cuvelier et al., 2006, Dunne and O'Neil, 1996, French et al., 1998, Madsen et al., 1991, O'Kiely et al., 2002, Rodbotten et al., 2002, Steinwidder et al., 2002, Weeler, 2005). In our previous studies (Legoshin et al., 2008, Mambetov et al., 1998) we have examined the impact of different concentrate level (from 30 to 65 percent) in rations on growing performance, carcass characteristics and economic efficiency of young dairy bulls. It was shown by these studies that the best ratio between biological and economic efficiencies of beef production was achieved when the diets consist of 40-45 percent of concentrates on dry matter basis. Taking into account these observation all animals in this project were reared on the diets which consist of medium quality forage (55 percent) and grain concentrates ( 45 percent).

\section{Material and Methods}

\subsection{Animals, Diets and Experimental Design}

The experiment was conducted at the Dubrovitsy experimental farm. Sixty bull calves used in this experiment were the progeny of high dairy genetic merit Holstein sires and high-productive (milk yield $\geq 8000 \mathrm{~kg}$ per lactation) Black and White dams with proportion of Holstein blood above 70\%. After a mean rearing period of $112 \pm 21$ days all bulls were assigned randomly to four groups scheduled to slaughter after reaching target live weights of 400, 450, 500 or $550 \mathrm{~kg}$. All animals were indoor housed in individual tie-up stalls. An identical mixed diet consisting (in dry matter basis) of corn (45\%) and grass (10\%) silages, barley and wheat-based concentrates $(44.5 \%)$ and a mineral/vitamin mixture $(0.5 \%)$ was given ad libidum after weighing to all the animals. The average chemical composition of the diet was a follows: dry matter (DM) $407 \mathrm{~g} / \mathrm{kg}$ fresh weight, crude protein content $12-14 \%$, metabolic energy concentration $10.7 \mathrm{MJ} / \mathrm{kg} \mathrm{DM}$.

\subsection{Traits, Methods of Assessments and Measurements, Statistics}

Unconsumed feed mixture was removed from the bunks and weighted on 10 days intervals to determine feed intake and feed conversion rate (DM intake/daily gain). The bulls were weighed at start of experiment (initial weights) and then every 30 days at the same time of day throughout experimental period, 3 days before slaughter (final weight, used for calculation of daily live weight gain, feed intake and feed conversion ratio) and before slaughter after $18 \mathrm{~h}$ of fasting (slaughter weight used for the calculation of killing-out and internal fat proportion). When the target slaughter weights were achieved, the bulls were slaughtered in the small experimental abattoir of the experimental farm Dubrovitsy ( 5 animals on each slaughter day). Within $1 \mathrm{~h}$ after slaughter, the carcasses were uniformly dressed and assessed by a trained classifier for conformation (EUROP scale 1 ( $\mathrm{P}=$-poorest) to 5 (E=best) and fatness (EUROP scale 1(L-leanest) to 5 (F-fattest) according to the EU Beef Carcass Classification 
Scheme (Commission of the European Communities, 1982) and for quality categories scale 1 (lowest) to 7 (the best) according to National Standard of Russian Federation GOST-P54315-2011, 2011, were calculated. The weights of hot carcasses and internal fat depots (kidney, heart, chanel and pelvic fats) were recorded. The killing out percentage was calculated as ratio (hot carcass weight/slaughter weight) x 100 . After cooling for $24 \mathrm{~h} \mathrm{pH}$ values were measured, the weights of both carcass sides were recorded and the right sides were divided into lean meat, bones and tendens. The musculus longissimus dorsi (MLD) area (ribeye area), and subcutaneous fat thickness were measured at the section between the 12 and 13 ribs.

The chemical composition (ash, dry matter, protein, fat) of meat was assessed on freezedried average meat samples and samples of the MLD according to official procedures.

The tenderness, expressed by its opposite, the toughness, was estimated by the measurement of the Warner-Bratzler peak Shear force (WBPSF).

In order to calculate the economic parameters the following indicators were controlled and calculated in the course of fattening: costs for feeds, labor costs and other costs, including costs for preventive and medical treatment, water supply, electricity, transport, depreciations, etc. On that basis the prime costs of live weight gain and of yield were calculated. After adding the value of the calf as a feeder, the full cost was calculated. Both prime costs and full costs were calculated for $1 \mathrm{~kg}$ of live weight and $1 \mathrm{~kg}$ of yield (carcass weight). The incomes from the sale and the profit were calculated on the basis of the relevant prices currently in use in Russia.

The basic statistical processing was carried out using the respective models of «Statistical» Software, №1234. All parameters included in this study are presented as mean $( \pm$ s.e.).

\section{Results}

\subsection{Feed Intakes and Live Weight Gain}

By design, there were no differences in ages and average daily live weight gains of animals from start of experiment to slaughter between the groups of bulls $(\mathrm{P}>0.37)$. As expected, days on feed and total dry matter intakes linearly increased with increasing live weights scheduled for slaughter $(\mathrm{P}<0.001)$, but feed conversion decreased $(\mathrm{P}<0.05$; table 1$)$.

Table 1. Feed intake and growth performance of young bulls slaughtered at different live weights

\begin{tabular}{|c|c|c|c|c|c|c|}
\hline & \multicolumn{4}{|c|}{$\begin{array}{l}\text { Target of live weights } \\
\text { at slaughter }(\mathrm{kg})^{1}\end{array}$} & \multirow[t]{2}{*}{ s.e. $^{2}$} & \multirow[t]{2}{*}{ Signifi-cance } \\
\hline & 400 & 450 & 500 & 550 & & \\
\hline Number of animals & 15 & 15 & 15 & 15 & 15 & \\
\hline Initial age (days) & 113.4 & 112.8 & 113.7 & 112.2 & 10.7 & NS \\
\hline Initial weights $(\mathrm{kg})^{3}$ & 147.2 & 146.7 & 148.0 & 146.9 & 21.4 & NS \\
\hline Days on feed & 255.2 & 314.1 & 365.8 & 403.6 & 25.1 & $\mathrm{xxx}$ \\
\hline Final live weights $(\mathrm{kg})^{4}$ & 402.9 & 454.5 & 510.2 & 549.7 & 47.9 & $\mathrm{xxx}$ \\
\hline Live weight gains $(\mathrm{kg})^{5}$ & 255.7 & 307.8 & 362.2 & 402.8 & 44.2 & $\mathrm{xxx}$ \\
\hline Average daily gain (g/day) & 1002 & 980 & 990 & 998 & 27.4 & NS \\
\hline \multicolumn{7}{|l|}{ Feed intake } \\
\hline Dry matter & & & & & & \\
\hline (DM, kg per animal) & 1571.2 & 1985.1 & 2470.4 & 2851.8 & 137.6 & $\mathrm{xxx}$ \\
\hline DM (kg/day per animal) & 6.16 & 6.32 & 6.82 & 7.08 & 0.15 & $\mathrm{xxx}$ \\
\hline $\begin{array}{l}\text { Feed conversion ratio } \\
\text { (kg DM intake per kg gain) }\end{array}$ & 5.91 & 6.45 & 6.89 & 7.09 & 0.19 & $\mathrm{xxx}$ \\
\hline
\end{tabular}

\footnotetext{
${ }^{1}$ Groups of animals in accordance with target slaughter weights.

${ }^{2}$ In this and subsequent tables s.e. for $\mathrm{n}=15$

${ }^{3}$ Live weights at start of experiment.

${ }^{4}$ Live weights 3 days before slaughter.

${ }^{5}$ Calculated as difference between final LW and initial LW.
} 


\subsection{Carcass Evaluation}

Carcass performance traits are given in tables 2. Higher values of killing out percent, subcutaneous fat thickness at $12^{\text {th }}$ rib, carcass weight on day of age but lower values of bone content were indicated for bulls slaughtered at older ages and heaver live weights $(\mathrm{P}<0.05-0.001)$. It is very important to determine that biological efficiency increased with increasing slaughter weights, but fatness of carcasses were acceptable for all age and slaughter weight groups of bulls. It was demonstrated that production systems with lighter slaughter weights require much more animals to produce $1000 \mathrm{~kg}$ of carcass weight in comparison with heavier animals.

The results of carcass grading by European and Russian Standards are given table 3.

It has been shown that carcass conformation scores $(\mathrm{P}<0.001)$, quality grade of carcasses by Russian standard $(\mathrm{P}<0.001)$, rib eye area $(\mathrm{P}<0.001)$, rib eye area per kilo of carcass weight $(\mathrm{P}<0.001)$ and tenderness $(\mathrm{P}<0.05)$ were improved with increasing of slaughter weights. But carcass conformation scores and carcass fatness scores were relatively low. In accordance with Russian National standard, quality grades of bulls slaughtered at live weight $550 \mathrm{~kg}$ were by $63.7 \%$ higher (Scores 6.55 vs 4.00 ) in comparison with animals slaughtered at live weight $400 \mathrm{~kg}(\mathrm{P}<0.001)$ because the main goal of Russian standard is to enhance the carcass weight of young animals.

Table 2. Carcass characteristics of young bulls slaughtered at different live weights

\begin{tabular}{|c|c|c|c|c|c|c|}
\hline & \multicolumn{4}{|c|}{$\begin{array}{l}\text { Target of live weights } \\
\text { at slaughter }(\mathrm{kg})^{1}\end{array}$} & \multirow[t]{2}{*}{ s.e. $^{2}$} & \multirow[t]{2}{*}{ Signifi-cance } \\
\hline & 400 & 450 & 500 & 550 & & \\
\hline Slaughter live weights $(\mathrm{kg})^{3}$ & 394.2 & 444.9 & 500.5 & 538.7 & 14 & $\mathrm{xxx}$ \\
\hline Hot carcass weights $(\mathrm{kg})$ & 212.5 & 242.5 & 276.3 & 300.5 & 4.69 & $\mathrm{xxx}$ \\
\hline Killing out $(\%)^{4}$ & 53.90 & 54.51 & 55.20 & 55.78 & 0.31 & $\mathrm{x}$ \\
\hline Fat thickness at $12^{\text {th }}$ rib. $(\mathrm{mm})$ & 1.7 & 1.9 & 2.2 & 2.6 & 0.07 & $\mathrm{xx}$ \\
\hline Internal fat weight $(\mathrm{kg})^{5}$ & 7.15 & 9.21 & 11.43 & 13.90 & 0.09 & $\mathrm{xxx}$ \\
\hline Internal fat $(\%)^{6}$ & 1.81 & 2.07 & 2.28 & 2.18 & 0.05 & $\mathrm{x}$ \\
\hline Bone content $(\%)^{7}$ & 21.0 & 20.7 & 18.9 & 17.9 & 0.12 & $\mathrm{xxx}$ \\
\hline Carcass weight per day of age $(\mathrm{g})^{8}$ & 529 & 526 & 576 & 583 & 14 & $\mathrm{x}$ \\
\hline $\begin{array}{l}\text { Number of bulls to produce } 1000 \mathrm{~kg} \text { of carcass } \\
\text { weight (number) }\end{array}$ & 4.70 & 4.12 & 3.62 & 3.33 & & \\
\hline
\end{tabular}

${ }^{1,2}$ See footnotes to table 1.

${ }^{3}$ Live weights before slaughter after $18 \mathrm{~h}$ of fasting.

${ }^{4}$ Calculated as ratio hot carcass weights and slaughter weights.

${ }^{5}$ Kidney, heart, chanel and pelvic fats.

${ }^{6}$ Calculated as ratio of internal fat weight and slaughter weight.

${ }^{7}$ Calculated as ratio of bone weight and carcass weight.

${ }^{8}$ Calculated by dividing of hot carcass weight on days of ages at slaughter.

${ }^{9}$ Calculated by dividing of $1000 \mathrm{~kg}$ on average carcass weight.

Table 3. Impact of different live weights at slaughter on carcass grading of young bulls

\begin{tabular}{|c|c|c|c|c|c|c|}
\hline \multirow[t]{2}{*}{ Item } & \multicolumn{4}{|c|}{$\begin{array}{l}\text { Target of live weights } \\
\text { at slaughter }(\mathrm{kg})^{1}\end{array}$} & \multirow[t]{2}{*}{ s.e. $^{2}$} & \multirow[t]{2}{*}{ Signifi-cance } \\
\hline & 400 & 450 & 500 & 550 & & \\
\hline Carcass conformation $^{3}$ & 1.37 & 1.49 & 1.52 & 1.89 & 0.081 & $\mathrm{xxx}$ \\
\hline Carcass fatness ${ }^{4}$ & 1.45 & 1.59 & 1.74 & 1.99 & 0.092 & $\mathrm{xxx}$ \\
\hline Quality grade by Russian standard ${ }^{5}$ & 4.00 & 5.00 & 5.70 & 6.55 & 0.177 & $\mathrm{xxx}$ \\
\hline Bone content $(\%)$ & 21.0 & 18.1 & 18.2 & 17.9 & 1.21 & $\mathrm{x}$ \\
\hline Rib eye area $\left(\mathrm{cm}^{2}\right)$ & 70.6 & 75.2 & 81.3 & 87.8 & 1.87 & $\mathrm{xxx}$ \\
\hline Rib eye area per $\mathrm{kg}$ of carcass weight & 0.332 & 0.310 & 0.294 & 0.292 & 0.004 & $\mathrm{xxx}$ \\
\hline
\end{tabular}


$\left(\mathrm{cm}^{2}\right)$

Tenderness $\left(\mathrm{kg} / \mathrm{cm}^{2}\right)^{6}$ 3.37 3.12 2.99 2.81 0.13 $\mathrm{X}$

${ }^{1,2}$ See footnotes to table 1 .

${ }^{3}$ EU Beef classification Scheme EUROP Scale 1 (poorest) to 5 (best).

${ }^{4}$ EU Beef classification Scheme EUROP Scale 1(leanest) to 5 (fattest).

${ }^{5}$ National standard of Russian Federation for beef carcasses classification Scale 1 (lowest category) to 7 (best-super category).

${ }^{6}$ Warner-Bratzler Shear force.

\subsection{Meat Chemical Composition and Economic Efficiency}

Meat chemical traits are given in Table 4. Numerous significant effects of slaughter weights were demonstrated on meat quality attributes. Higher $\mathrm{pH}$ values $(\mathrm{P}<0.001)$, higher dry matter $(\mathrm{P}<0.05-0.001)$, and fat $(\mathrm{P}<0.001)$ content but lower protein content $(\mathrm{P}<0.05-0.01)$ were observed in meat samples from heavier and older animals.

Table 4. Impact of different live weights at slaughter on meat chemical composition of young bulls

\begin{tabular}{|c|c|c|c|c|c|c|}
\hline \multirow[t]{2}{*}{ Item } & \multicolumn{4}{|c|}{$\begin{array}{l}\text { Target of live weights } \\
\text { at slaughter }(\mathrm{kg})^{1}\end{array}$} & \multirow[t]{2}{*}{ s.e. ${ }^{2}$} & \multirow[t]{2}{*}{ Signifi-cance } \\
\hline & 400 & 450 & 500 & 550 & & \\
\hline \multicolumn{7}{|l|}{ MLD: } \\
\hline pH $24 h$ post mortem & 5.60 & 5.64 & 5.71 & 5.74 & 0.01 & $\mathrm{xxx}$ \\
\hline Dry matter $(\%)$ & 22.37 & 23.31 & 23.70 & 24.06 & 0.27 & $\mathrm{x}$ \\
\hline Protein $(\%)$ & 21.12 & 21.59 & 21.78 & 21.89 & 0.21 & $\mathrm{x}$ \\
\hline Fat $(\%)$ & 0.76 & 1.23 & 1.42 & 1.67 & 0.02 & $\mathrm{xxx}$ \\
\hline \multicolumn{7}{|l|}{ Average meat sample } \\
\hline Protein $(\%)$ & 20.05 & 19.68 & 19.55 & 19.12 & 0.15 & $\mathrm{xx}$ \\
\hline Fat (\%) & 8.35 & 12.28 & 14.57 & 16.22 & 0.12 & $\mathrm{xxx}$ \\
\hline Dry matter $(\%)$ & 28.91 & 32.47 & 34.63 & 35.84 & 0.27 & $\mathrm{xxx}$ \\
\hline
\end{tabular}

${ }^{1,2}$ See footnotes to table 1 .

Economic efficiency of modern dairy beef production systems in Russia are given in Table 5. Under Russian conditions, proportion of feeder costs (in our experiment at the age of approximately 4 months) depends on slaughter weights and decreased from 39 percent for group animals slaughtered at live weight $400 \mathrm{~kg}$ to 27.8 percent for heaviest animals. Net return increased with increasing slaughter weights $(\mathrm{P}<0.001)$. But profitabilities were unchanged and were relatively low. it is very important to remark that in accordance with our findings (Table 2) the production systems with highest slaughter weights of animals in comparison with the lightest slaughter weights ( $550 \mathrm{vs} 400 \mathrm{~kg}$ ) require less number of bulls by 41.1 percent to produce $1000 \mathrm{~kg}$ of carcass weight.

Table 5. Impact of different live weights at slaughter on economic efficiency of dairy beef production system

\begin{tabular}{|c|c|c|c|c|c|c|}
\hline \multirow[t]{2}{*}{ Item } & \multicolumn{4}{|c|}{$\begin{array}{l}\text { Target of live weights } \\
\text { at slaughter }(\mathrm{kg})^{1}\end{array}$} & \multirow[t]{2}{*}{ s.e. $^{2}$} & \multirow[t]{2}{*}{ Signifi-cance } \\
\hline & 400 & 450 & 500 & 550 & & \\
\hline Cost of bull at start (rubles) ${ }^{3}$ & 13248 & 13203 & 13320 & 13221 & 121 & N.S. \\
\hline Feed cost of gain (rubles) ${ }^{4}$ & 13433.8 & 16972.6 & 21121.9 & 24382.9 & 207 & $\mathrm{xxx}$ \\
\hline Other costs of gain(rubles) $)^{5}$ & 7233.6 & 8743.5 & 10403.3 & 11474.3 & 99 & $\mathrm{xxx}$ \\
\hline $\begin{array}{l}\text { All costs of gain(rubles per } \\
\text { animal) }\end{array}$ & 20337.4 & 25332.2 & 30611.1 & 34342.1 & 232 & $\mathrm{xxx}$ \\
\hline Total costs of bull (rubles) ${ }^{6}$ & 33915.4 & 38535.2 & 43931.4 & 47563.1 & 311 & $\mathrm{xxx}$ \\
\hline Return per one bull (rubles) ${ }^{7}$ & 37187 & 42437 & 48353 & 52588 & 302 & $\mathrm{xxx}$ \\
\hline Net return per one bull (rubles) ${ }^{8}$ & 3271.6 & 3901.8 & 4421.6 & 5024.9 & 75 & $\mathrm{xxx}$ \\
\hline
\end{tabular}




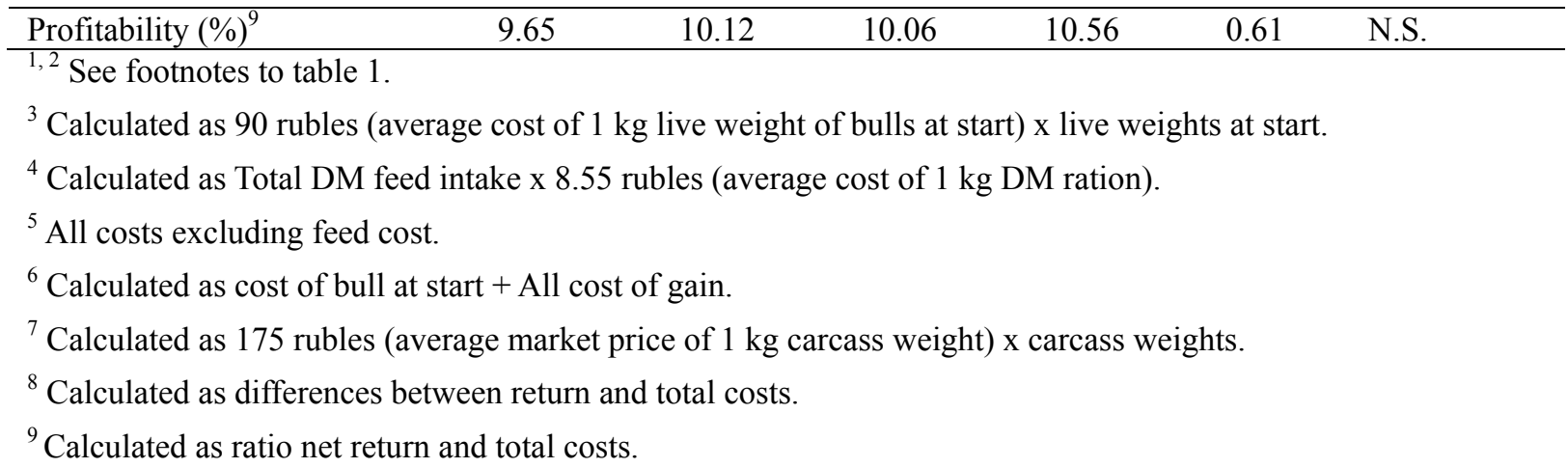

\section{Discussion}

In many countries, as well in Russia, the main source of beef is the fattening contingent from the dairy farms. It has been shown by many studies (Madsen et al., 1992, Otonzborov, 2004, Steinwidder et al., 2002, Waritthitham et al., 2010, Wheeler et al., 2005) that the increase in beef production has resulted from the increase of slaughter weights of young cattle. Our findings have demonstrated that at the present time in Russia optimum slaughter weights of young dairy bulls are 500-550 kg at the ages of 17-18 months. This conclusion is confirmed by our assessments of growing-finishing performance, carcass traits and profitability of modern dairy beef production system. Biological efficiency as measured by carcass weight production per animal, carcass and meat qualities, increased with increasing of slaughter weights from 400 to $550 \mathrm{~kg}$. The same pattern was occurred for net return. In this connection we have stated one negative factor, namely, decreasing feed conversion. This fact may be explained by differing composition of gain (i.e., heaver animals deposited more fat than did lighter animals). This suggestion was confirmed by carcass characteristics. It was indicated that quantities $(\mathrm{P}<0.001)$ and proportion $(\mathrm{P}<0.05)$ of internal fat were increased with increasing slaughter weights (table 2$)$. In contrast Bureš and Bartoň, 2012, reported that there was no significant difference in feed conversion between age (14 vs 18 months) and slaughter weight (554.3 vs $698.0 \mathrm{~kg}$ ) groups of bulls. But many researchers (Anderson et al., 2005, Antal et al., 1988, Brosh et al., 1995, Dunne and O'Neil, 1996, Fallon et al., 2001, Frickh et al., 2002, and others) have shown the negative impacts of age and slaughter weights of animals on feed conversion. It has been shown in our experiment, that carcass conformation scores of all groups of bulls were relatively low (1.45-1.89) as well as filthiness scores (1.45-1.99). This result of carcass grading in accordance with EUROP system may be explained by high proportion of Holstein genes in bulls involved in experiment.

Our assessments of carcass conformation and fatness, other carcass traits and meat production's potential of modern Black and White bulls with high proportion of Holstein blood are in agreement with many other studies. For example, Mc Gee et al., 2007, (Ireland) concluded that there were large differences between high dairy genetic merit Holstein and standard dairy genetic merit Friesian in body and carcass measurements, and hence in carcass shape and compactness (carcass conformation score 1.51 for Holstein and 2.15 for Friesian bulls) but differences in live weight gains and carcass weights were small.

\section{Conclusions}

Summary, present study has shown clear increasing biological and economic efficiencies of dairy beef production systems with increasing slaughter weights of animals up to $550 \mathrm{~kg}$ when in these systems are used Black and White bulls. Increasing slaughter weights increased carcass weights, killing out proportion and improved some quality characteristics of carcasses and meat. The meat potential of modern Black and White breed with $\geq 85$ percent of Holstein blood remains good enough to produce high quality lean carcasses in accordance with Russian National standard and EUROP standard as well. Practical implication of present observations i.e. necessary of fattening of dairy bulls to the live weights $500-550 \mathrm{~kg}$ instead of $370 \mathrm{~kg}$ (average slaughter weights of young cattle in Russia in 2013) has very high importance for increasing beef production in Russia. At the same time there are some problems to be investigated in the future and among them how to improve the feed conversion and economic efficiency of dairy beef production systems.

\section{Acknowledgements}

The technical input of Dubrovitsy experimental farm staff and the analyses by Chemical Laboratory of L.K. Ernst Institute of Animal Husbandry are acknowledged with gratitude. 


\section{References}

Alberti, P., Ripoll, G., Goyache, F., Lahoz, F., Olleta, J. L., Panea, B., \& Sanudo, C. (2005). Carcass characterization of seven Spanish beef breeds slaughtered at two commercial weights. Meat Science, 71, 514-521. http://dx.doi.org/10.1016/j.meatsci.2005.04.033

Alberti, P., Panea, B., Sanudo, C., Olleta, J. L., Ripoll, G., Ertbjerg, P., Christensen, M., Gigli, S., Failla, S., Renand, G., Nute, G. R., Richardson, R. I., \& Williams, J. L. (2008). Live weight, body size and carcass characteristics of young bulls of fifteen European breeds. Livestock Science, 114, 19-30. http://dx.doi.org/10.1016/j.livsci.2007.04.010

Amerchanov, H. A., Strekozov, N. I., \& Seltsov V. I. (2013). The breeds of dairy cattle. In N.I. Strekozov and H.A. Amerchanov (Eds), Dairy cattle husbandry of Russia (24-26). Moscow.

Anderson, R. V., Rasby, R. J., Klopfenstein, T. J., \& Clark, R. T. (2005). An evaluation of production and economic efficiency of two beef systems from calving to slaughter. J. Animal Science, 83, 694-704.

Antal, J., Bulla, J., \& Uhrin, V. (1988). [Meat] performance of the Slovak pinzgau cattle of different live weights. Salent. Agr. Bogemoslow, R. 21(H. 2), 109-118.

Brosh, A., Aharoni, Y., Levy, D., \& Holzer, Z. (1995). Effect of diet energy concentration and age of Holstein-Friesian bull calves on growth rate, urea space and fat deposition, and ruminal volume. Journal of Animal Science, 73, 1668-1673.

Bureš, D., \& Barton, L. (2012). Growth performance, carcass traits and meat quality of bulls and heifers slaughtered at different ages. Czech J. Anim. Sci., 57(1), 34-43.

Clinquart, A., Istasse, L., Dufrasne, I., Mayombo, A., Eenaeme, C., \& Bienfait, J. M. (1991). Effects on animal performance and fat composition of two fat concentrates in diets for growing-fattening bulls. Animal Production, 53, 315-320. http://dx.doi.org/10.1017/S0003356100020316

Commission of the European Communities (Beef Carcass Classification) Regulations. Council Regulations 1358/80, 1208/81, 1202/82. Commission Regulations 2930/81, 563/82, 1557/82, Commission of the European Communities, Brussels.

Cuvelier, C., Cabaraux, J. F., Dufrasne, I., Clinquart, A., Hocquette, J. F., Istasse, J., \& Hornick, J. L. (2006). Performance, slaughter characteristic and meat quality of young bulls from Belgian Blue, Limousin and Aberdeen Angus breeds fattened with a sugar-beet pulp or a cereal-based diet. J. Animal Science, 82, 125-132. http://dx.doi.org/10.1079/ASC20057

Dunne, W., \& O'Neil, R. (1996). Efficient grass based dairy beef production systems. Abstract. In Irish Journal of Agricultural and food Research, 35(1), 84.

Fallon, R. J., Drennan, M. J., \& Keane, M. G. (2001). Bull Beef Production. Occasional Series 2, Teagasc, Grange Research Centre, 16 pages.

French, P. O., Riordan, E. C., Moloney, A. P., O Kiely, P., Humphreys, J., \& Caffrey, P. J. (1998). The effects of concentrate level and systems of herbage allowance on beef production in the autumn. Proc. 24-th Irish Grassland animal Production Association Research conference, 101-102.

Frickh, J. J., Steinwidder, A., \& Baumung, R. (2002). Effect of ration, sex and slaughter weight on slaughtering performance of Simmental cattle. Zuchtungskunde, 74, 362-375.

Hardy, R., \& Meadowcroft, S. (1990). Indoor beef production. ISBN 0-85236-160-2, Farming Press, London, $1-155$.

Keane, M. G., \& Fallon, R. J. (2001). Effects of feeding level and duration on finishing performance and slaughter traits of Holstein-Friesian bulls. Irish Journal of Agricultural and Food Research, 40, 145-160.

Keane, M. G., \& Darby, T. E. (2000). Beef production from dairy calves. In M. G. Keane (Ed.), Profitable Production of Quality Beef. ISBN: 184170125x: 28-31.

Keane, M. G. (2003). Development of an intensive Dairy Calf-to Beef System and Associated Grassland management. End of Project Report, Grange Research Centre, project No. 4582. Beef Production Series, 40, $1-28$.

Kwon, E. G., Park, B. K., Kim, H. C., Cho, Y. M., Kim, T., Chang, S. S., ... Choi, N. J. (2009).Effects of fattening period on growth performance, carcass characteristics and lipogenic gene expression in Hanwoo steers. Asian-Australian Journal of Animal Sciences, 22, 356-362. 
http://dx.doi.org/10.5713/ajas.2009.90257

Legoshin, G. P., \& Sharafeeva, T. G. (2013). Fattening of young cattle at the modern feedlots. Dubrovitsy, 1-76.

Legoshin, G. P., Dzuba, N. F., Mogilenetz, O. N., Afanasyeva, E. S., \& Golovina, T. G. (2008). Effects of selenic additive Sel-Plex on finishing performance, carcass characteristics and meat quality of Black-and-White dairy bull calves. J. Zootechnia (Russia), 11, 14-16.

Madsen, N. T., Madsen, P., \& Andersen, B. B. (1992). Effect of carcass pricing systems on optimum slaughter weight, energy level in feed and choice of sirebreed in beef dairy breed young bull production. Acta Agric. Anim. Sci., 42(1), 47-53.

Mambetov, M. M., Mogilenetz, O. N., \& Legoshin, G. P. (2006). Effects of different level of nutrition on performance and carcass traits of finishing dairy bull calves. Journal of Dairy and Beef Cattle Husbandry (Russia), 1, 16-17.

McGee, M., Keane, M. G., Neilan, R., Moloney, A. P., \& Caffrey, P. J. (2007). Body and carcass measurements, carcass conformation and tissue distribution of high dairy genetic merit Holstein, standard dairy genetic merit Friesian and Charolais $\times$ Holstein-Friesian male cattle. Irish Journal of Agricultural and Food Research, 46, 129-147.

Mossberg, I., lindell, L., \& Johnsson, S. (1992). Two housing systems for intensively reared bulls slaughtered in two weight ranges. Acta Agric. Scand. Sect. A., 42(3), 167-176.

National Standard of Russian Federation GOST-R 54315-2011. The Cattle for slaughter. Beef and Veal in carcasses and semi-carcasses. Technical conditions. Moscow, Standardinform.

O'Kiely, P., Moloney, A., \& O'Riordan, E. G. (2002). Reducing the cost of beef production by increasing silage intake. Grange Research Centre, Dunsany, Ireland. Beef production series, 51, 1-69.

O'Neill, R., \& Dunne, W. (1995). Beef from the dairy herd with or without subsidies. Abstract. In Irish Journal of Agricultural and Food Research, 34, 1-76.

Orkisz, T. (1988). Koszty opasu buhajow w przedziale masy ciala od 150 go 650 kg. Ins. Zootechniki, Krakow, Biul. Informacyjny, Rok XXVI, 5-6, 3-19.

Otonzborov, R. (2004). Study on the effect of some biological and economic factors on the profit in fattening beef bullocks. Trakia J. Sci., 2(4), 10-16.

Rodbotten, R., Hildrum, K. I., \& Berg, J. (2002). Effects of concentrate level on carcass composition, tenderness and growth rate of Angus x NRF and Limousin x NRF bulls. Acta Agricultural Scandinavia, Section A, Animal Science, 52, 72-80. http://dx.doi.org/10.1080/09064700212073

Steinwidder, A., Frickh, J., Luger, K., Guggenbeger, T., Schauer, A., Huber, J., \& Gruber, L. (2002). Effect of ration, sex and slaughter weight on feed intake and fattening performance of Simmental cattle. Zuchtungskunde, 74, 104-120.

Walsh, K., O'Kiely, P., Moloney, A. P., \& Boland, T. M. (2008). Intake, performance and carcass characteristics of beef cattle offered diets based on whole-crop wheat or forage maize relative to grass silage or ad libidum concentrates. Livestock Science, 116, 223-236. http://dx.doi.org/10.1016/j.livsci.2007.10.010

Waritthitham, A., Lambertz, C., Langolz, H., Wicke, M., \& Gauly, M. (2010). Assessment of beef production from Brahman $\mathrm{x}$ Thai native and Charolaise $\mathrm{x}$ Thai native crossbred bulls slaughtered at different weights. II : Meat quality. Meat Science, 85, 196-200. http://dx.doi.org/10.1016/j.meatsci.2009.12.025

Wheeler, T. L., Cundiff, L. V., Shackelford, S. D., \& Koohmar-aie, M. (2005). Characterization of biological types of cattle (Cycle VII): carcass, yield, and longissimus palatability traits. J. Animal Science, 83, 196-207.

\section{Copyrights}

Copyright for this article is retained by the author(s), with first publication rights granted to the journal.

This is an open-access article distributed under the terms and conditions of the Creative Commons Attribution license (http://creativecommons.org/licenses/by/3.0/). 